\title{
The Heat Treatment Impact on Material Properties of 34CrNiMo6 Steel
}

Mariana Janeková, Daniela Koštialiková, Andrej Dubec, Matej Burget, Františka Pešlová

Faculty of Industrial Technology in Púchov, Alexander Dubček University of Trenčín, I. Krasku 491/30, Púchov 020 01 Púchov, Slovakia. E-mail:mariana.janekova@fpt.tnuni.sk, daniela.kostialikova@fpt.tnuni.sk, andrej.dubec@fpt.tnuni.sk, matejburget@centrum.sk, frantiska.peslova@fpt.tnuni.sk

An article deals with the assessment of the heat treatment of the material for a particular machine component. This material is $34 \mathrm{CrNiMo6}$, made of two melts. This steel belongs to a group of materials with special properties for working at higher temperatures and for the production of demanding components, turbine wheels, cardan shafts, toothed wheels. The material was evaluated for microstructure quality before and after heat treatment. Based on metallographic microstructures, it is possible to review the heat treatment mode, which subsequently affects the mechanical properties of the components. For a particular design element, better cast material was recommended based on a comprehensive evaluation.

Keywords: Heat Treatment, Microstructure, Melt, Steel, Fracture

\section{Introduction to the problems to be solved.}

In technical practice, regarding the heavy loaded components, the 34CrNiMo6 material is frequently used. This material is resistant to the long-term mechanical stresses in different surroundings [1]. For this reason, there are the exacting requirements on the primary metallurgy. This technology has to guarantee homogeneous and highgrade steel structures with respect to their material properties $[1,2,3]$.

Taking into consideration, that DIN EN10204- 3.1 standard, allows a certain range in percentage of individual chemical elements, there are the cases that the same steel casts in different melts will vary within an allowed range. This results in a different response of these materials to the same heat treatment $[2,3,4]$.

A presented work deals with problem, which occurred after the heat treatment of the particular components [5]. From two different melts, two identical components as regards to design, were made of $34 \mathrm{CrNiMo} 6$ material [6,
7,8]. But after the heat treatment of individual component, particular components behaved in different ways. One component was of high-quality in terms of both, structure and mechanical properties, in contrast to the other one that cracked after final processing.

\section{Experimental part}

This experiment was aimed at the determination of the major causes of fracture of component which was made out of primary melt. Difference of chemical composition (in terms of standards) of primary melt in comparison with other melt of the same material, which was certificated as satisfying, was minimal.

In order to solve this problem, the material from two different melts was supplied. The chemical composition of the material is shown in the Tab.1.

The given table shows the content of the particular chemical elements for the individual melts (melt No.1 and melt No.2) according to the standard as well as values obtained by chemical analysis

Tab. 1 Chemical composition of 34CrNiMo6 material.

\begin{tabular}{|l|c|c|c|c|c|c|c|c|}
\hline Element (wt.\%) & C [\%] & Si [\%] & Mn[\%] & P [\%] & S [\%] & Cr[\%] & Mo[\%] & Ni[\% ] \\
\hline Melt No.1 & 0.34 & 0.23 & 0.67 & 0.012 & 0.023 & 1.48 & 0.19 & 1.44 \\
\hline Melt No.2 & 0.34 & 0.22 & 0.67 & 0.015 & 0.026 & 1.58 & 0.22 & 1.48 \\
\hline 34CrNiMo6 (according to & $0.30-$ & max. & $0.50-$ & $\max$. & $0.020-$ & $1.30-$ & $0.15-$ & $1.30-$ \\
DIN EN 10204-3.1.) & 0.38 & 0.40 & 0.80 & 0.035 & 0.035 & 1.70 & 0.30 & 1.70 \\
\hline
\end{tabular}

Predetermined and measured values of material properties are listed in Tab. 2. The mentioned standard also allows relatively large variations of material properties of 34CrNiMo6 steel.

Tab. 2 Predetermined and measured values of the material properties of 34CrNiMo6 steel.

\begin{tabular}{|c|c|c|}
\hline Parameter & Unit & HMS 155/Melt No.1/No.2 \\
\hline $\begin{array}{ll}\text { Yield point } & \text { Rp02 } \\
\end{array}$ & MPa & $\min .850 / 1110 / 950$ \\
\hline Tensile strength $\mathrm{Rm}$ & MPa & $1000-1200 / 1180 / 1060$ \\
\hline Ratio $\quad$ Rp02 / Rm & --- & $0.84-0.94 / 0.93 / 0.86$ \\
\hline Ductility & $\%$ & $\min .13 / 13 / 9$ \\
\hline Contraction $\quad \mathrm{Z}$ & $\%$ & $\min .50 / 55 / 26$ \\
\hline Impact test ISO-V & $\mathbf{J}$ & $\min .45 / 55 / 45$ \\
\hline
\end{tabular}

According to the HMS 155, hardness of the examined material is specified within the range $310-390 \mathrm{HB}$. As regards the melt No.1, measured average hardness was approximately $325 \mathrm{HB}$. Hardness for material of melt No.2 was appr. 355 HB. Taking into consideration, that standard allows relatively large variance of hardness for 
this material (up to $80 \mathrm{HB}$ ), measured average values do not show variances of hardness in individual areas of the component.

The experimental part dealt with study and evaluation of the microstructure of both components (disrupted as well as intact) after the heat treatment. The attention was paid to micro-purity as well as fracture areas which have been examined after static tensile test performed for both melts materials.

\section{Using microscopy to analyse the quality of 34CrNiMo6 material.}

The quality of primary metallurgy is reflected in keeping of the prescribed chemical composition as well as purity of the microstructure because it subsequently affects the material properties $[4,8]$. For microscopic evaluation, a large number of locations were selected (from both analysed components), from which the samples were cut and metallographically prepared. From a large number of measurements, this paper provides only those images which represented specified experiment.

\section{Micro - purity of the materials.}

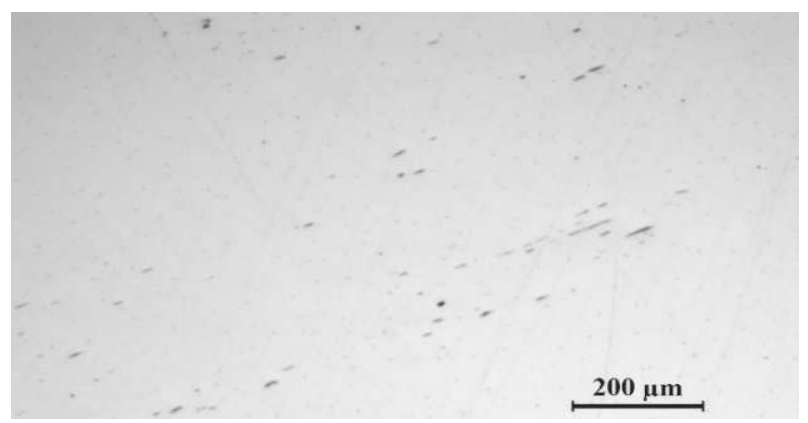

a) Melt No. 1

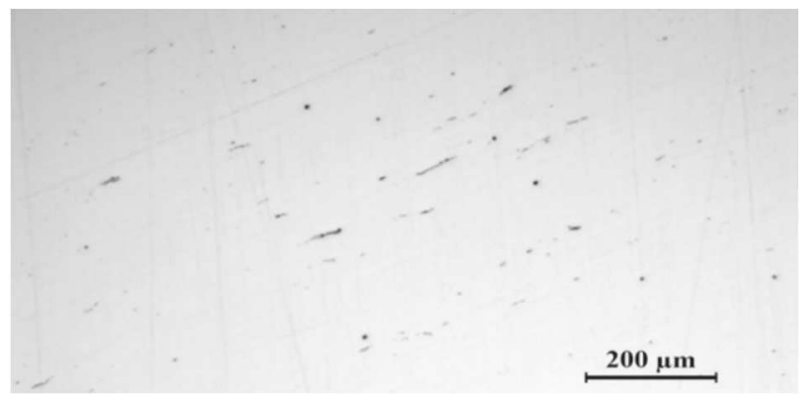

b) Melt No.2

Fig. 1 Micro-purity of Melt No.1 and No.2

The micro-purity of tested materials has always been evaluated for two cuts in a cross-sectional direction, with respect to the technological principles of casting and forgings processing. At the examined locations of metallographically prepared materials (melt No.1 and melt No.2), the occurrence of non-metallic inclusions, sulphide phases, dot oxides and inductile silicates (according to STN EN 10247, with effect from 1.9.2007) was identified and classified.

The micro-purity of melt No.1, can be summarised as follows:

- dot oxides, grade: 2 ,

- $\quad$ sulphides, grade: 2 ,
- $\quad$ non-formable silicates, grade: 2 ,

The micro-purity of melt No.2, can be summarised as follows:

- dot oxides, grade: 2,

- $\quad$ sulphides, grade: 3 ,

- non-formable silicates, grade: 3, (in compliance with STN EN 10 247).

In melt No.2, the alignment of carbide phases occurred more clearly Fig. 1 .

The accumulation of sulphides with silicates causes stresses, which results in brittleness of the material [5].

Therefore it will be necessary to find the difference relating to the type of morphology and arrangement of each intermediate phases for particular locations.

\section{Surface changes of microstructure}

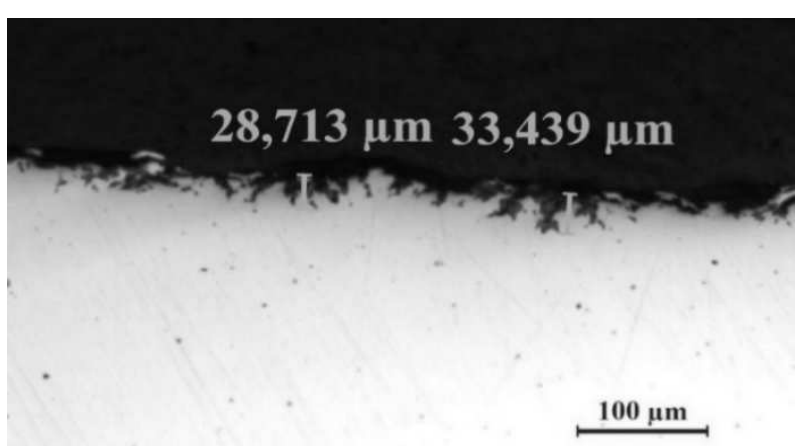

Fig. 2 Presence of oxide phases and change of roughness in the surface layer - melt No.1

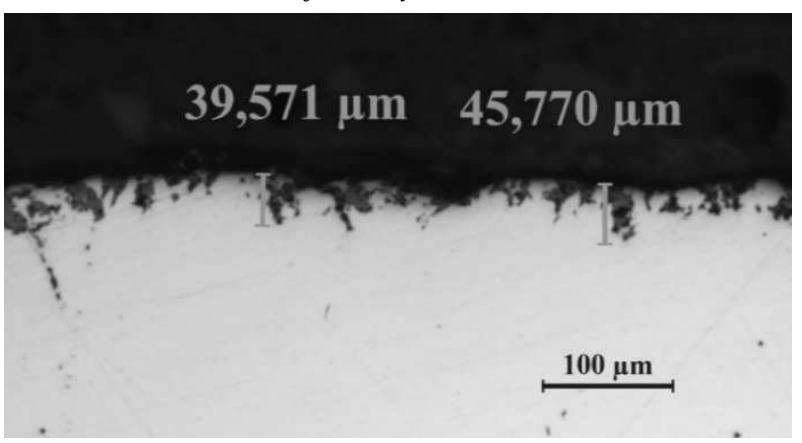

Fig. 3 Oxide phases and change of roughness from the selected area-melt No.2

During the heat treatment process (e.g. when cooling in liquid medium), some materials are sensitive to the formation of oxides, which results in change of the surface microstructure.

In the case of surface change, the roughness increases and it leads to initiation propagation of the crack, standing for the rupture [6].

For this reason, attention was paid to the character as well as thickness of oxide layers, which appeared at the investigated locations.

The oxide thicknesses were not arranged uniformly and even oxide phase could be observed at high depth in primary structure. Such cases result in initiation of the rupture as well as occurrence of intercrystalline corrosion. 
In relation to melt No.1, the measured depth of oxide phases in the basic material was within the range app. 35 $\mu \mathrm{m}$ Fig. 2. For melt No.2, depth in some places was up to app. $70 \mu \mathrm{m}$ Fig.3. We have always measured a large number of areas in long sections Fig.4, but for presentation of disrupted surface areas and future initiations of rupture, only selected details are documented.

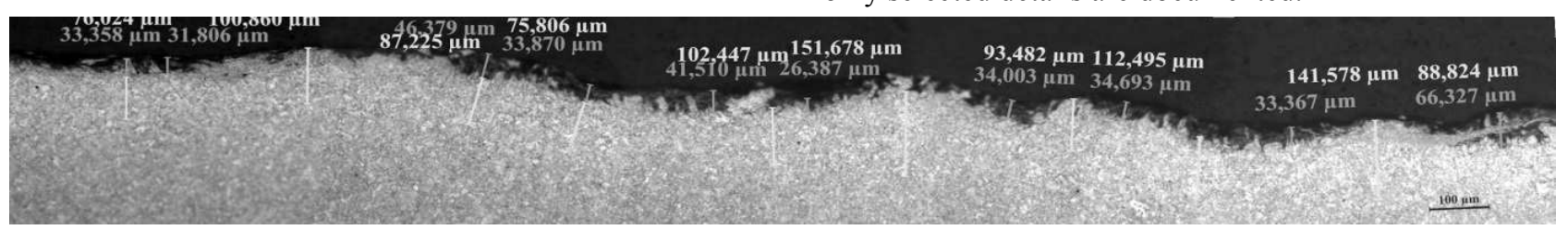

Fig. 4 Measured surface changes - Melt No.2

\section{Evaluation of microstructure after heat tre- atment}

Relating to both melts (nital etching $2 \%$ ), from a large number of randomly selected locations of 34CrNiMo6 steel, the metallographically prepared microstructures were examined and evaluated.

Examination of the melt No.1:

At the joined areas, shown Fig. 5, the microstructure appeared to be relatively evenly arranged, with slight alignment of the structure.

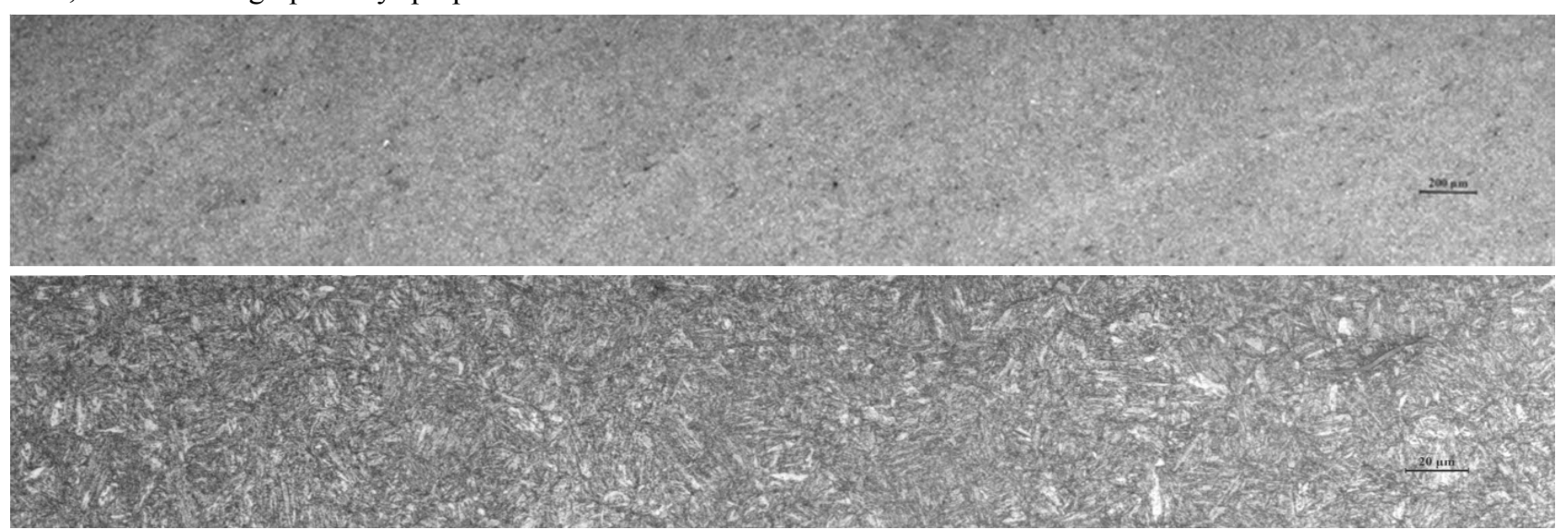

Fig. 5 Microstructure of 34CrNiMo6 steel-Melt No. 1

This microstructure can be classified as martensiticbainite, high tempered - sorbitic, without any free ferrite occurrence. This sorbitic microstructure is fine and evenly arranged. Based on cementite evaluation, with compliance SEP 1520, after stronger etching the structure of melt No.1, was:

- carbon size corresponds to grade: 2 ,

- $\quad$ carbidic mesh corresponds to grade: 5 ,

According to the regulation HMS 155 and in compliance with SEP 1520, occurrence of cementite should meet following parameters:

- $\quad$ carbon size: $\max : 2.2$

- $\quad$ carbidic mesh: max: 5.2
In the subsurface regions of both components there was even partial decarburization, which was continuously monitored. In the case of the melt No.1, the thickness of decarburization was relatively smaller than that of the No.2. For melt No.1, average decarburization was about $50 \mu \mathrm{m}$, but in melt No.2 it was up to $150 \mu \mathrm{m}$ Fig. $4-($ green colour represents oxidation, yellow one represents decarburization).

\section{The melt No.2:}

The microstructure from the melt No. 2 was typical by the occurrence of inclusions and more continues alignment of carbidic phases Fig. 6 and $\mathbf{6 a}$.
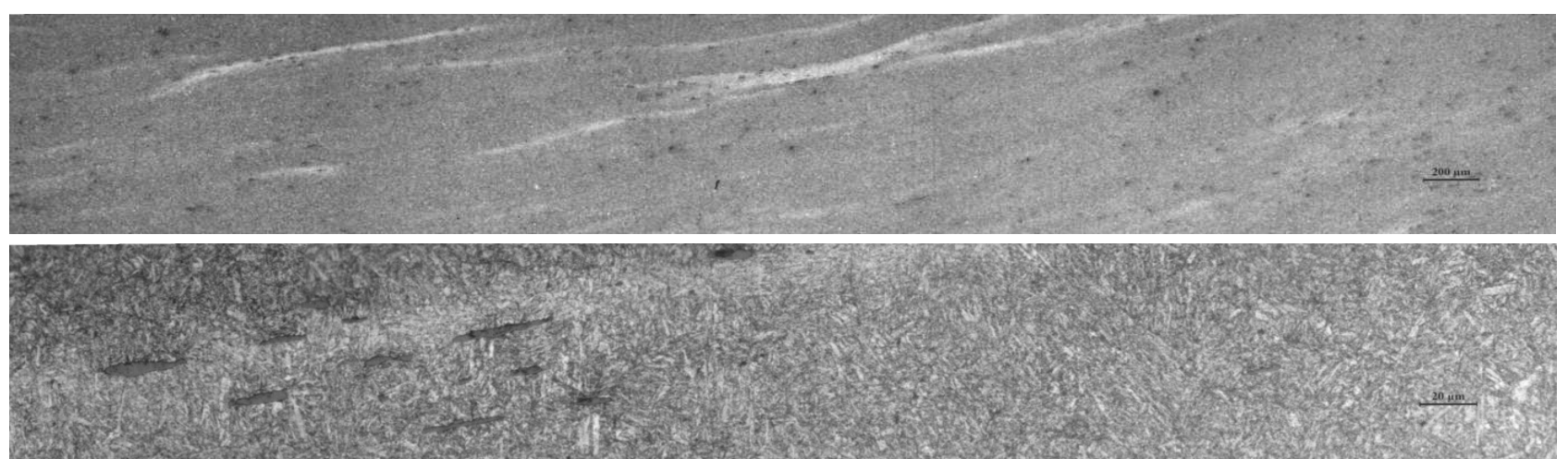

Fig. 6 Microstructure of material - melt No.2 
The evaluation of cementite, according to the SEP 1520 , after stronger etching of structure, for melt No.2 results in as follows:

- $\quad$ carbon size corresponds to grade: 2.2

- $\quad$ carbidic mesh corresponds to grade: 5.2

According to the regulation of HMS 155 and in compliance with SEP 1520, occurrence of cementite should meet following parameters:

- $\quad$ carbon size max: 2.2

- $\quad$ carbidic mesh max: 5.2
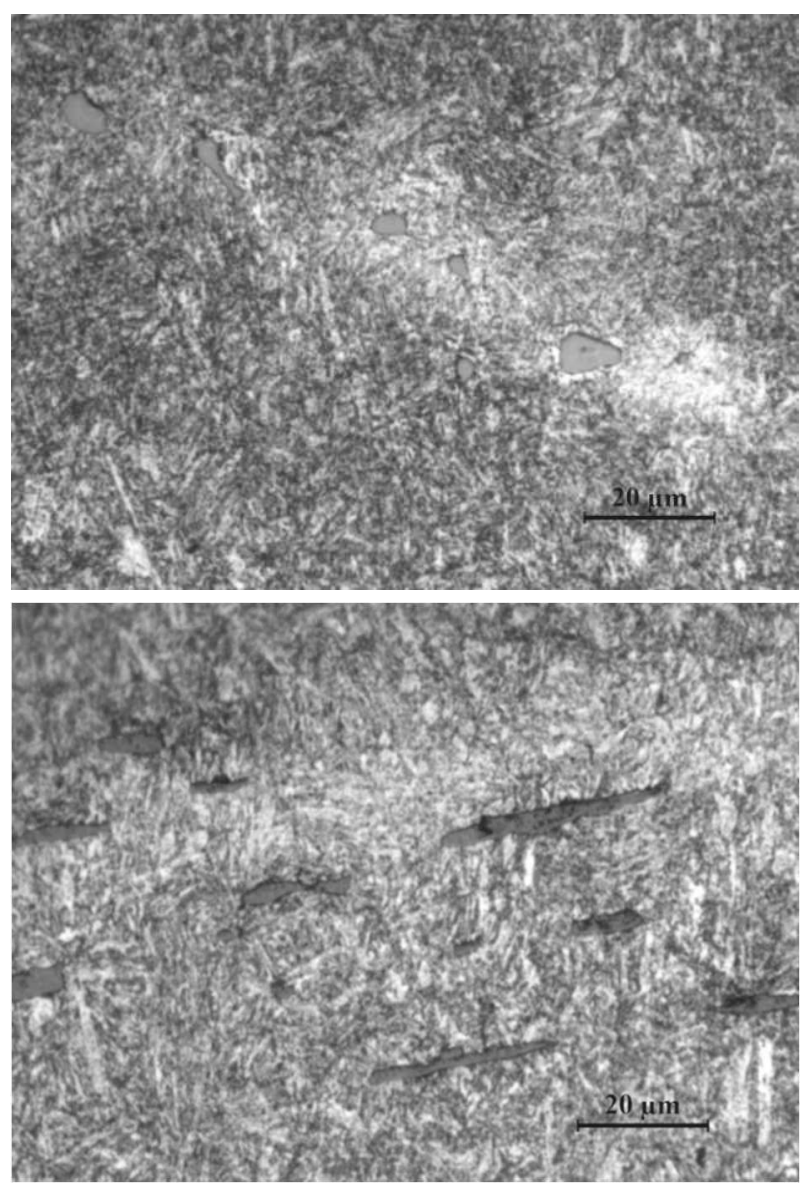

Fig. 6a Details of material microstructure - melt No. 2

The heterogeneous microstructure of the melt No.2 can also be defined as martensitic - bainite (high tempered - sorbitic), without occurrence of free ferrite, displayed in Fig. 6.

From microscopic point of view, it can be stated, that this is a microstructure after the heat treatment of relatively large components, which have been hardened and consequently tempered. It is clear, that in case when heat treatment does not result in dissolution of the carbides or decay of the silicates, in some locations, the heterogeneity of primary obtained structure can be intensive. If such a situation occurs in the case of thin walls of the castings or forgings, there is a consequent weakening of strength of structural parts.

\section{Evaluation of the fracture areas.}

By their character and morphology, fracture areas (artificially created, or after mechanical tests) indicate and complete information on microstructure imperfection $[9,10]$. The fracture of the melt No.1 was in the form of rosette Fig.7, corresponding to deformation of the standard material.
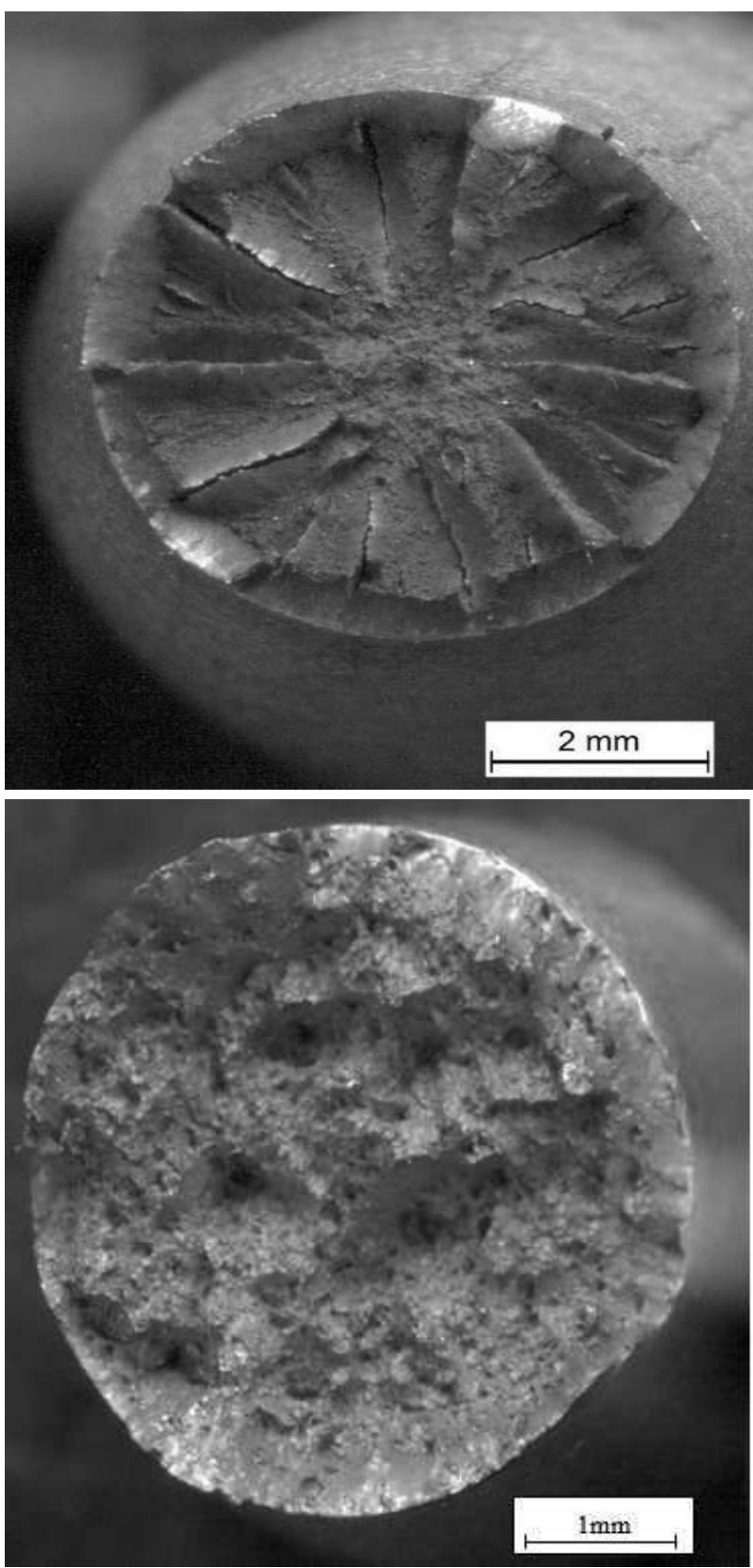

Fig. 7 Fracture areas of material - melt No.1 and melt No. 2

The morphology of the fracture area of melt No.2 was in the form of stone fracture Fig. 7, and it is connected with the evidence of material brittleness and moreover, it was also confirmed by low values of ductility and contraction $T a b .2$. A detailed analysis of the fracture surface gave proof to the presence of eutectic interdendritic formations of sulphide inclusions. The researched facts indicated an undesirable distribution of sulphides in particular area of the material. In the case of occurrence of sulphides in the form of a line in a rosette arrangement, the stress arises in this micro-location, which is superposed by occurrence of silicates and the material becomes very brittle in this location. 


\section{Conclusion}

By comparing the results from the evaluation of the two melts of the same $34 \mathrm{CrNiMo} 6$ material, it was confirmed, that the difference in chemical composition, although it is in compliance with stated standard, can have negative appearance even after further technological processing. In case of large volume components it is apparent, because if there is a difference of heterogeneity either in structural or chemical composition, there is the occurrence of such areas in which the fracture is initiated. If undesirable phases in the form of sulphides, carbides and silicates are present in the material, different melts of the identical materials may have different properties. This can be also influenced by geometry and design of the final structural element.

After the heat treatment, there is a possibility of superimposition of the stress in the microlocallites, in which the undesirable phases remained undissolved. In case of needle arrangement of the microstructure (e.g. martensite with residual heterogeneous phases), there is an accumulation of stress, which becomes a reason of breaking. In terms of strength, these areas can be defined as so-called weak spots, which are potential reason of the breaking.

Such situation occurred in the case of analysed component that cracked. Even though it was made of the same material, the different melt for its casting was used. The distribution of the undesirable phases was the cause of the high stresses in incriminated areas. Another undesirable factor, occurring in melt No.2, was decarburization of the surfaces, which is not allowed by the standard in case of these materials.

It can be concluded that the chemical and structural heterogeneity in components, even after heat treatment, superposes stress - strain states. We recommend continues testing of the chemical composition for each material, before its utilisation. For heavy loaded components, it will be necessary not only to perform microscopic investigation of the material purity, but also evaluate the microstructure quality before and after the heat treatment.

\section{Acknowledgement}

This paper deal was supported by the Slovak Grant Agency KEGA 007TnUAD -4/2017, VEGA grant No. 1/0649/17, VEGA grant No. 1/0589/17 and resulted from the project „, Center for quality testing and diagnostics of materials", ITMS code 26210120046 relating to the Operational Program Research and Development funded from European Fund of Regional Development.

\section{References}

[1] DAŇA, M., ZETEK, M., SCHORNÍK, V (2017). Cutting Tool Life when Tapping Nickel Based Super Alloy, Manufacturing Technology, No. 1, Vol. 17, (2017) ISSN 1213-2489, p 18-23.
[2] KEJZLAR, P., MACHUTA, J., NOVÁ (2017). Comparison of the Structure of CuZn40MnAl Alloy Casted into Sand and Metal Moulds. Manufacturing Technology, No. 1, Vol. 17, (2017) ISSN 1213-2489, p 44-48.

[3] LÉGÁT, V., ALEŠ, Z., HLAdÍK, T. (2017).Maintenance Audit: the Tool for Maintenance Management Quality of Manufacturing Equipment. Manufacturing Technology, No. 1, Vol. 17, (2017) ISSN 1213-2489, p 53-62.

[4] MAJERNÍK, J., KMEC,J., KARKOVÁ, M. (2017).Analysis of the Impact of the Construction of a Gate on the Macroscopic Structure of a Casting and Its Influence on the Mechanical Properties of Castings. Manufacturing Technology, No. 1, Vol. 17, (2017) ISSN 1213-2489, p 62-66.

[5] STUDENÝ, Z., DOBROCKÝ, D., POKORNÝ, Z. (2017).Importance of Diffusion Process on the Fatigue Life of Steel .Manufacturing Technology, No. 1, Vol. 17, (2017) ISSN 1213-2489, p 94-99.

[6] ZETEK, M., ZETKOVÁ, I (2017).Influence of the Workpice Quality on the Cutting Tool Life when Gear Wheel are Machined. Manufacturing Technology, No. 1, Vol. 17, (2017) ISSN 1213-2489, p 121-125.

[7] HLUCHÝ, M., MODRÁČEK, O., PAŇÁK, P. (2002). Strojírenská technologie I. Metalografie a tepelné spracovaní. Praha, 2002. ISBN 80-7183265-0.

[8] JANOVEC, J., DOMÁNKOVÁ, M., GRGAČ, P., GÖMŐRY, F., KUSÝ, M. (2012). Progresívne materiály a technológie. Bratislava. Slovenská technická univerzita, 2012. ISBN 978-80-2273648-0.

[9] KLOPANOVÁ, V., NOVÁK,V., KVASNOVÁ,P., NOVÁK, D. (2017). Theoretical Basis of Fractographic Methods and Their Application in Fracture Modelling for Cr-Ni Steels Manufacturing Technology, No. 6, Vol. 17, (2017) ISSN 1213-2489, p 869-876.

[10] HAZLINGER, M., MORAVČÍK, R. (2007). Degradačné procesy a predikcia životnosti. Slovenská technická univerzita v Bratislave.2007 ISBN 978-80-8096-031-5. 